\title{
千畑一郎博士の第 1 回国際酵素工学賞受賞
}

米国工学財団(Engineering Foundation)主催, 第 7 回 国際酵素工学会議(International Conference on Enzyme Engineering VII, ICEE VII) が 1983 年 9 月 25 日よ り30 日までの間米国ペンシルベニア州ホワイトヘブン のポコノ・ハーシー・リゾートで開かれた. 酵素工学に 関する最先端の講演, 濃縮された討論等非常に得るとこ ろの多い会議であったが，何といっても，日本からの参 加者 (19名) にとって最も大きなイベントは千畑一郎博 士（田辺製薬株式会社研究開発本部長）の第 1 回酵素工 学賞受賞であった.

ICEE は米国工学財団の主催する数々の国際会議の 1 つで, 1971 年米国, ニニーハンプシャー州へニカーでの 第 1 回会議の後 2 年ごとに開催され今回が第 7 回とな る. 1981年には福井三郎京大名誉教授, 鉿木周一東工大 教授および千畑一郎博士が中心となって組織された第 6 回会議が三重県賢島で開催されたことは記憶に新しいと ころである. なお工学財団は, Warner \& Swasey 商会 の設立者である Ambrose Swasey 氏の遺贈により 1914 年に設立されたもので, 現在米国の土木，機械，化学工 学等を含む 5 学会の代表で管轄されている.この会議の 特徴は参加者を約 200 人に限定し, 全員を同一の宿泊所 に 6 日間帯在させ，1つの会場で午前中および夜に各約 3 時間ずつ講演・討論が行われることである. 講演は研 究の展望と自分の研究を合せた内容であり，1週間で酵 素工学に拈ける世界の潮流を知ることができる，この講 演のスピーカーとなるのは大変名誉なことであり, 今回 は日本の代表として協和醱酵工業の鮫島廣年博土, 東工 大の鈴木周一教授 - 軽部征夫博士, 名大農の山根恒夫博 士が講演された. 最もホットな情報は午後のポスターセ ッションで発表される. 酵素工学を専門としたこのよう な世界的な会議は汪かに例がなくこの分野では最高の レベルの会議であるといえる. 事実, 参加者のなかには酵 素工学の先駆者であるイスラエルの前大統領 Katchalski Katzir 教授を始めとして, 世界各国の権威者が颜を並べ ている、またこの会議のも51つの特徵は, 非常に家 族的な雲囲気であることである，午後の休み時間はもら ろん夜の会議後のソーシャルアワーでは先酒を汲み交わ しながら時には午前 1 時ごろまで, 詳細な討論が行わ れ, 新進の研究者も容易に話の輪のなかへ入ることがで
きる、このよらな会議において，今回初めて酵素工学賞 が制定され，国際授賞委員会が第 1 回の受賞者として千 畑一郎博士を選んだわけである。授賞式は会議 5 日目 9 月 29 日に開かれた.

会議主催の受賞記念のカクテルパーティが日本人参加 者および外国䂺究者の主たった人々の参加のもとに開か れた後，バンケットに入った：バンケットが佳境に入 るとタイミングよく，組織委員長の Dr. A.I. Laskin (Exxon Research \& Engineering Company) より授賞 のアナウンスがなされ千畑一郎博士の名前の刻まれた美 しいStueben glass (Corning Glass Works 社提供, 写 真 3 参照）が授与された. また会議のディレクターであ る工学財団 Dr.S.S. Cole 上り賞状（写真 3 )が手渡され た. 千畑博士の受賞講演 (写真 2) が終了すると参加者全 員より暖かい拍手が会場から沸き上がり博士の受賞を祝

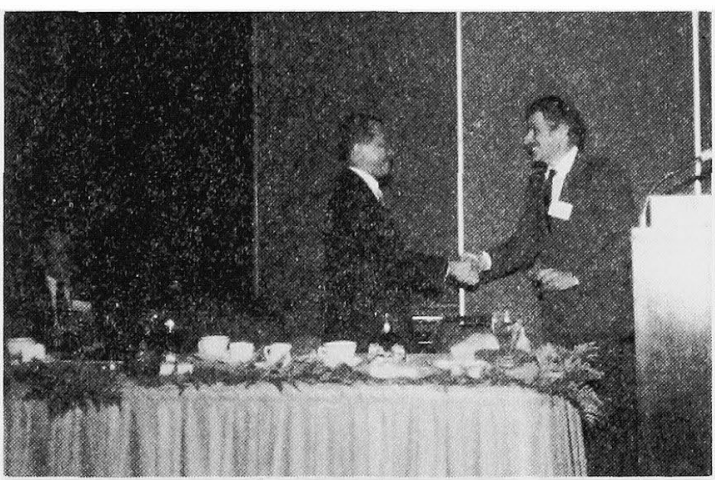

写真 1 授賞式で A. L. Laskin 博士と握手する 千畑博士

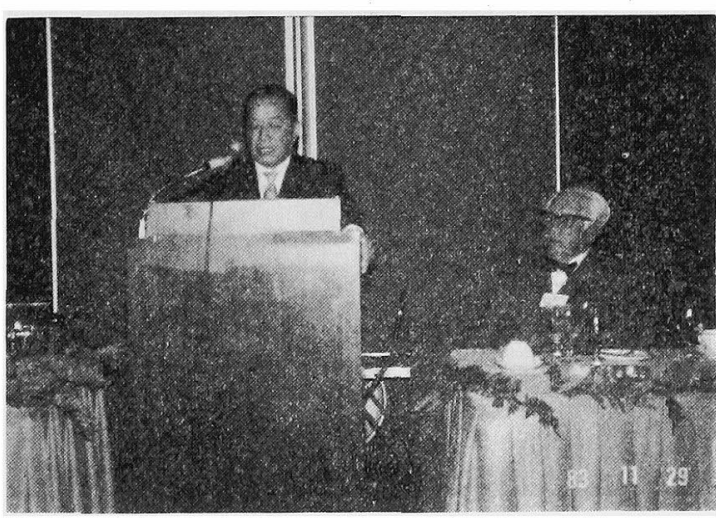

写真 2 千畑博士の受賞講演 
福した、授賞式の後には日本の酵素工学研究会主催の答 礼のパーティが会長の福井教授，副会長の鈴木教授の音 頭で開かれ，主だった外国人招待者と，日本人参加者が千 畑博士および Stueben glass ・ 賞状を围んで再度祝福し, エキサイティングな1日を終光た．今回の千畑博士の受
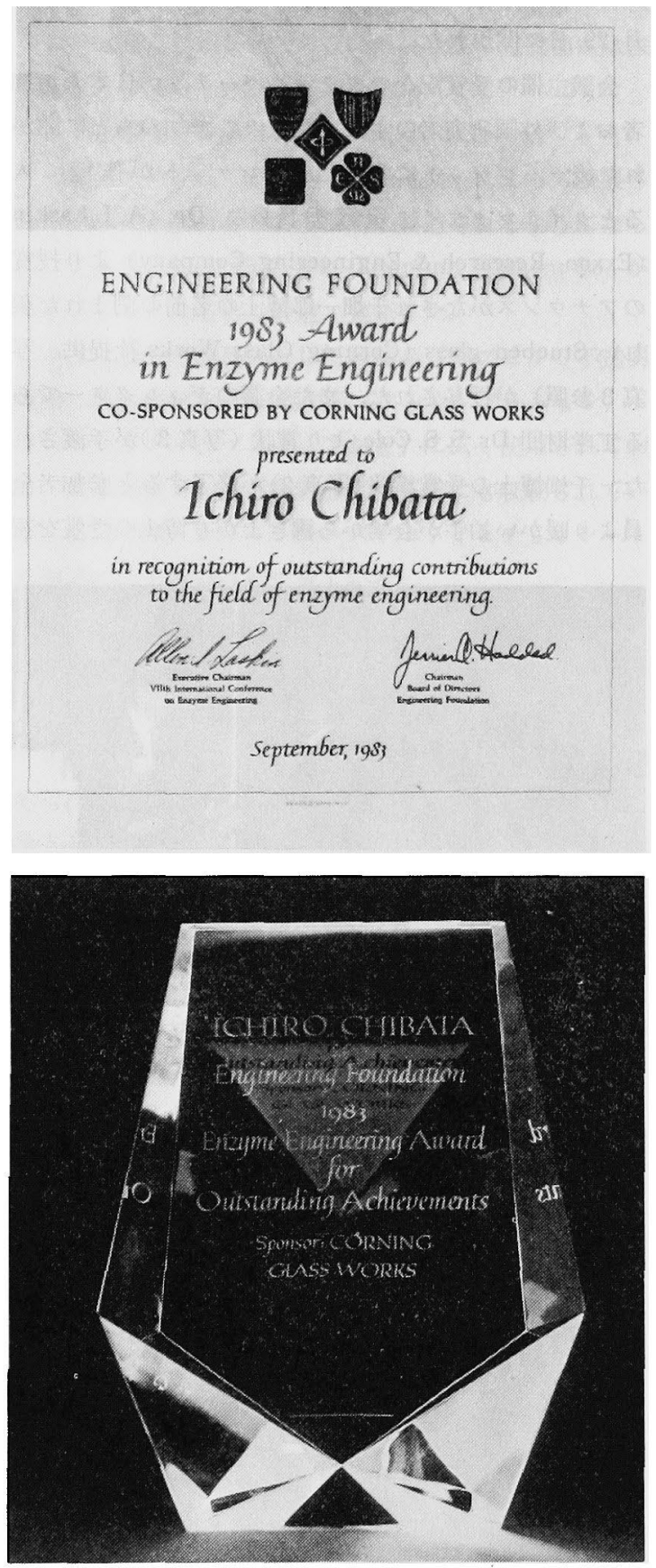

写真 3 表彰状と記念の Stueben glass
賞は博士はもとより，一緒に研究された方々にとって本 当に喜ばしいことであるが，パーティで福井・鈴木両教 授が述べられたように，日本の酵素工学研究会にとって も名覓であるばかりでなく，研究者 1 人 1 人にも大きな 励みである。

さて，授賞の対象となった研究開発について簡単に述 ベる.

千畑博士らは田辺製薬において, アミノ酸合成とラセ ミ体アミノ酸の光学分割の研究を行い，1953 年にアセ チル-DLーメチオニンの合成とそ机の Aspergillus oryzae 起源のアミノアシラーゼによる不斉水解によるメチオニ ン合成法を工業化し，さらに L-リジン， L-トリプトファ ンの製造システムへ発展させていた。このような下地の もとに, 1960 年代の初期より固定化アミノアシラーゼに 関する基礎研究が進められ，1969 年に DEAE-Sephadex

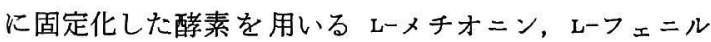
アラニン， Lーバリン等の製造の工業化に成功された．こ れが固定化酵素の工業化の世界で最初の例であることは よく知られている.酵素工学は現在急速に進歩しつつあ るバイオテクノロジーの基幹であるから，この成功例は バイオテクノロジーの実用化の幕開きといっても過言で ないであろう。ささらに千畑博士らは 1960 年よりフマル 酸アンモニウムよりバッチ醱酵法で し-アスパラギン酸 を製造していたが，アスパルターゼ活性を持つ E. coli をポリアクリルアミドゲルに固定化し，連続的にアスパ ラギン酸を製造する方法を開発し，1973 年に工業化し た.これは世界で初めての固定化静菌体の実用化例とな った. 1974 年には固定化 Brevibacterium ammoniagenes (フマラーゼ，担体はアクリルアミドゲル)によるリン ゴ酸の工業生産を開始した，その後，固定化法の改良が 進められ，上法はそれぞれ 1978 年, 1977 年に たーカラ ギーナンによる固定化法に変更されている.1982 年には フマル酸アンモニウムから L-アスパラギン酸を経由す る L-アラニンの製造を $2 つ の$ 固定化菌体カラムリアク ターをシークエンシャルに用いる方法で開始している. この反応のうち第 2 の反応は脱炭酸反応であり，脱炭酸 に伴ら $\mathrm{pH}$ 変化を抑えるため高压カラム型りアクターを 用いる工夫がなされている。このほか 法による固定化生菌体(イースト)を用いるアルコール生 産方法の開発, 固定化タンニンの分離への応用等実際に 即したニニークな基礎および開発研究がなされている. 現在世界中には 7 種類の固定化生体触媒利用システムが 
工㘹化されているが，そのうち4つのシステムが千畑博 土执よび共同研究者の手によってなされたことには，た だただ警模するのみである.

千畑博士らの開発研究の跡をたどってすぐに気がつく ことは，どの開発をとってみても，それぞれすすばらし いターゲットを持っていたことであり，それが開発を成 功させた第1の要因と考学られる.最初の開発は，ア、 ノ酸の光学分割という難問を，固定化醳素を用いて行う ことを目的としている.すなわち分離を固定化酵素によ って行括うとしている. 固定化醉素の発想はもとると, 反応液と䤃素の分離を容易にして，酵素自身は反応によ って変化しないことをフルに生かそうといらすのであ る. 固定化醉素の最初の実用化例が，分離を行いやすく した固定化䤃素によって困難な分離を行らことであった ことは, バイオテクノロジーの将来の方向に大きな示唆 を与学るよらに思ら。すなわち、バイオテクノロジーの 最初の目的は效率のよい物質変換であるが，同時に分離 のことを十分に考光ておかないと成功しにくいといらこ とである、話が横道にそれたが，千畑博士らのすばらし いターダットが生まれたよりどころにす注目すべきであ ろう、いずれの場合も，それをでの段階を追ったなみな みならぬ開発研究の努力の下地が存在している.千畑博 土は受賞講演に扎いて，自ら，博士らの研究はターゲッ
トオリエンテッドでありけっして固定化法を研究した のでその利用の道を考皇たのではないと述べられた。 の言苯のなかに博士らの開発研究の真骨頂を見る気がす るとともに，筆者らが行ら大学での研究とは立場が買な るとはいえ，つい宿りやすい研究のための研究に対して の強い警鐘と受け取るべきのように思う。

千畑博士らの一連の研究報告を見てわかることである が，いったんターゲットが定をると，その目標達成のた めに，本来の専門分野を越兄るまでの広い範团でしかる 詳細な基礎研究が進められている。このよらにして得た scienceをこれまで培われた芸術ともいらべき technologyに適用し，見事に engineering として結契された ことが，世界の多くの大学，研究所，会社等の著名な競 争相手を淩いで第 1 回酵素工学賞受賞者に選ばれた理由 であろう.ちなみに酵素工学の工学は technology でな く engineeringである.千畑博士らの研究のますますの ご発展を新るとともに，筆者ら後進のご指導をお願いい たす次第である.

なお千畑博士はこれまで，大河内記念技術賞（1973 年), 科学技術庁長官賞 (1976 年), 紫粰褒賞 (1977 年). ヴィルタネン記念賞 (1979 年, 農化誌Vol. 54 , No. 1,61（1980）参照）等数多くの賞を受賞されている.

(京都大学農学部 松野隆一) 